\title{
Addition Effect of Aromatic Amines on Coal Fluidity and Coke Strength
}

\author{
Hiroshi Otsuka ${ }^{1)^{*}}$, Yusuke Dohi ${ }^{1)}$, Takashi Matsuil) and Kazutoshi Hanada ${ }^{2)}$ \\ 1) Steel Research Laboratory, JFE Steel Corporation \\ 2) JFE Steel Corporation, now JFE Techno-Research Corporation
}

Abstract: Coal fluidity is an important parameter in coal blending techniques for coke making because it strongly influences coke qualities. On the other hand, recently, the amount of high fluidity coal has been limited. To cope with this problem, caking additive method which improves fluidity of coal has been developed and commercialized. However, since tight supply of high fluidity coal is anticipated in the future, it is of great importance to develop more effective caking additive. Therefore, in this study, we investigated effect of 11 kinds of polyaromatic hydrocarbons which include oxygen, sulfur and nitrogen containing compounds on coal fluidity in order to search for more effective chemical substances. The additives were added to low fluidity coal, and fluidity analyses were carried out according to the Gieseler plastometer method. Addition of sulfur and oxygen containing compounds lowered fluidity of coal, whereas addition of aromatic amines enhanced fluidity of coal. Coal fluidity ameliorated with increasing the molecular weight of aromatic amine, and N, N'-di-2-naphthyl-1, 4-phenylenediamine (DNPD) was the most effective aromatic amine in this study. Carbonization tests in an electric furnace were conducted to investigate an effect of DNPD on coke strength. As a result of adding only $1 \mathrm{wt} \%$ DNPD, fluidity of blended coal and coke strength (Drum Index) were highly improved.

Keywords: cokemaking; coal thermoplasticity; caking additive; aromatic amine; slightly caking coal.

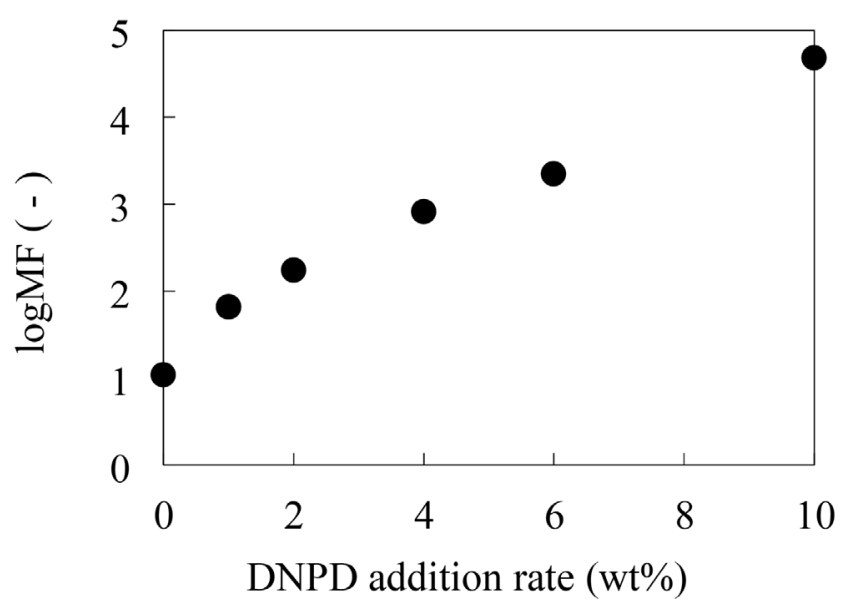

Received on Feb. 10, 2021 ; Accepted on Apr. 15, 2021 ; J-STAGE Advance published on May 14, 2021 ; originally published in ISIJ Int., Vol.59 (2019), No.8, pp.1413-1418

* Corresponding author. E-mail: hi-otsuka@jfe-steel.co.jp, Address: JFE Steel Corporation, 1 Kokan-cho Fukuyama Hiroshima 7218510 


\title{
石炭の流動性およびコークス強度に対する 芳香族アミンの添加効果
}

\author{
大塚 啓司 ${ }^{1)} *$ 土肥 勇介 ${ }^{1)} \cdot$ 松井 貴 $^{1)} \cdot$ 花田 一利 ${ }^{2)}$
}

Addition Effect of Aromatic Amines on Coal Fluidity and Coke Strength

Hiroshi Otsuka, Yusuke Dohi, Takashi Matsui and Kazutoshi Hanada

\section{1. 背景}

近年，高炉用コークスの製造プロセスに扎いて，低還元 材比操業の観点から高強度コークスの製造に対する要求が ますます高まっている ${ }^{1)}$ 。コークス用の原料炭の「粘結性」 は高強度コークス製造において, 最も重要な石炭配合指標 の一つである ${ }^{2)}$ 。特に，ギーセラープラストメータ法 (JIS M8801）で測定する流動度は粘結性を評価する指標して広 く利用されている。一方で, 流動性の高い良質な原料炭の 量は限られており, 高品質な原料炭の需給のタイト化およ び価格の上昇は避けられない課題であることから, 非微粘 結炭を利用する技術の開発が求められてきた。本課題解決 のため, 石炭の流動性を向上させる「粘結材添加法」が開 発・商業化されている ${ }^{3-7)}$ 。粘結材は, 石炭の流動性を改善 し, 液相炭化を促進してコークスの異方性組織を増加させ ることが知られている。一方で, 粘結材が石炭の流動性を 改善する機構は，いまだ十分には明らかになっていない。 石炭の流動性改善に有効な化学物質の探索のためには, 粘 結材添加法の機構を明らかにすることが重要である。

石炭の流動性向上に対して有効な化学物質を明らかにす るために, 石炭と化学物質の相互作用に関する多くの研究 が行われている ${ }^{8-10)}$ 。Koyano ${ }^{9)}$ は, 多環芳香族化合物が 石炭流動性に及ぼす影響を調査しており, より高沸点かつ 高分子量の多環芳香族が石炭の流動性とコークス強度に 優れた効果を持つことを報告している。Tsubouchi ら ${ }^{10)}$ は, 様々な含窒素芳香族が石炭の流動性とコークス強度に及ぼ す影響を調査しており，窒素含有芳香族化合物の中ではイ ンドールが石炭流動性およびコークス強度の向上に有効で あることを報告している。一方で, 流動性および強度向上 機構については完全には明らかになってはいない。

本研究では, より有効な化学物質を探索するために, 石
炭の流動性に及ぼす含酸素, 含硫黄および含窒素官能基を 有する 11 種の多環芳香族炭化水素の影響を調査した。さら に, 配合炭の流動性とコークス強度に及ぼす添加材の影響 を調べるために, 配合炭の流動性試験と乾留試験を行った。

\section{2. 添加材の基礎検討}

\section{$2 \cdot 1$ 実験}

\section{$2 \cdot 1 \cdot 1$ 試料}

Table 1 に石炭試料の特性データを示す。石炭試料のギー セラープラストメータ法による特性值 (軟化開始温度, 最 高流動度温度, 固化温度, 最高流動度), ビトリニットの平

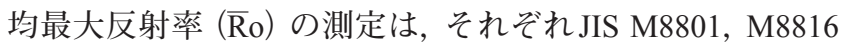
に準拠して行った。今回用いた添加材を Table 2 に示す。添 加材の官能基と石炭の流動性との関係を調べるために, 含 酸素官能基, 含硫黄官能基, 含窒素官能基を有する添加材 を選定した。含酸素官能基を有する添加材としてメトキシ フェノール, ヒドロキノンおよびアントロン, 含硫黄官能 基を有するジベンゾチオフェンを選定した。含窒素官能基 を有する添加材としてアクリジン, さらに芳香族アミンと して分子量および沸点が異なる $\mathrm{N}-$ フェニル-1-ナフチル

Table 1. Table1 Properties of coal A.

\begin{tabular}{|c|c|c|c|c|c|}
\hline \multicolumn{2}{|c|}{$\begin{array}{l}\text { Proximate analysis } \\
\text { (wt } \% \text { d.b.) }\end{array}$} & \multicolumn{4}{|c|}{$\begin{array}{l}\text { Ultimate analysis } \\
\text { (wt } \% \text { d.a.f.) }\end{array}$} \\
\hline ASH & VM & $\mathrm{C}$ & $\mathrm{H}$ & $\mathrm{N}$ & $\mathrm{S}$ \\
\hline 7.9 & 22.1 & 82.6 & 4.18 & 1.63 & 0.37 \\
\hline \multicolumn{4}{|c|}{ Gieseler properties } & $\overline{\mathrm{R}} \mathrm{o}$ & Total Inert \\
\hline $\operatorname{IST}(\mathrm{K})^{* 1}$ & $\operatorname{MFT}(\mathrm{K})^{* 2}$ & $\mathrm{ST}(\mathrm{K})^{* 3}$ & $\log M F$ & $(\%)$ & $(\%)$ \\
\hline 732 & 750 & 780 & 1.0 & 1.22 & 36.9 \\
\hline
\end{tabular}

*1: Initial Softening Temp., *2: Maximum Fluidity Temp., *3: Solidification Temp.

原著論文: ISIJ Int., Vol.59 (2019), No.8, pp. 1413-1418

2021 年2月 10 日受付 2021年4月15日受理２021年5月14日J-STAGE早期公開 (Received on Feb. 10, 2021; Accepted on Apr. 15, 2021; J-STAGE Advance published on May 14, 2021 ; originally published in ISIJ Int., Vol.59 (2019), No.8, pp.1413-1418)

1）JFEスチール (株) スチール研究所 (Steel Research Laboratory, JFE Steel Corporation)

2）JFEスチール（株）(現：JFEテクノリサーチ（株））(JFE Steel Corporation, now JFE Techno-Research Corporation)

* Corresponding author. E-mail : hi-otsuka@jfe-steel.co.jp, Address: JFE Steel Corporation, 1 Kokan-cho Fukuyama Hiroshima $721-8510$ 
アミン, カルバゾール, フェノチアジン , N, N'-ジ-2-ナ フチル-1，4-フェニレンジアミン（以下 DNPD）を使用し た。へテロ元素を含まない炭化水素としてデカヒドロナフ タレン，テトラリンを用いた。

$2 \cdot 1 \cdot 2$ ギーセラー流動度試験

石炭と添加材の混合物の流動度をギーセラープラスト メータ法 (JIS M8801) に準拠して実施した。石炭を粒径が $425 \mu \mathrm{m}$ 以下に粉砕し，添加材の割合が $10 \mathrm{wt} \%$ となるよう 混合して, 混合試料 $5.0 \mathrm{~g}$ を坩堝に装入し, 測定した。

\section{$2 \cdot 1 \cdot 3$ 熱分析}

芳香族アミンと石炭の熱的挙動の影響を確認するため, Coal A，DNPD，およびCoal AとDNPDの混合物（DNPD $10 \mathrm{wt} \%$ ) の熱重量測定（TG）を行った。測定はThermo Plus TG8120（Rigaku）を用いて, 試料量 $5 \mathrm{mg}$, 室温から $1273 \mathrm{~K}$ まで昇温速度 $5 \mathrm{~K} / \mathrm{min}, A r$ 雰囲気下の条件で実施した。

\section{$2 \cdot 2$ 結果と考察}

Fig.1にCoal A およびCoal Aに各種添加材を $10 \mathrm{wt} \%$ 添加 した水準の MFを示す。添加材はCoal Aに対し, 添加時に

Table 2. Properties of coal additives.

\begin{tabular}{|c|c|c|c|c|c|c|c|c|c|}
\hline \multirow{2}{*}{ Category } & \multirow{2}{*}{ Additives } & \multirow{2}{*}{$\begin{array}{c}\text { Melting } \\
\text { point } \\
\left({ }^{\circ} \mathrm{C}\right)\end{array}$} & \multirow{2}{*}{$\begin{array}{c}\text { Boiling } \\
\text { point } \\
\left({ }^{\circ} \mathrm{C}\right)\end{array}$} & \multirow{2}{*}{$\begin{array}{l}\text { Molecular } \\
\text { weight } \\
(\mathrm{g} / \mathrm{mol})\end{array}$} & \multicolumn{5}{|c|}{ Element ratio of additives (wt $\%$ ) } \\
\hline & & & & & $\mathrm{C}$ & $\mathrm{H}$ & $\mathrm{O}$ & $\mathrm{N}$ & S \\
\hline \multirow{3}{*}{ Oxygen-containing } & Methoxyphenol & 56 & 243 & 124.14 & $67.7 \%$ & $6.5 \%$ & $25.8 \%$ & & \\
\hline & Hydroquinone & $172-175$ & 285 & 110.11 & $65.4 \%$ & $5.5 \%$ & $29.1 \%$ & & \\
\hline & Anthrone & $154-157$ & 721 & 194.23 & $86.6 \%$ & $5.2 \%$ & $8.2 \%$ & & \\
\hline \multirow{2}{*}{ Hydrocarbon } & Decahydronaphthalene & -40 & 190 & 138.25 & $86.9 \%$ & $13.1 \%$ & & & \\
\hline & Tetralin & -35.8 & $206-208$ & 132.2 & $90.9 \%$ & $9.1 \%$ & & & \\
\hline Sulfur-containing & Dibenzothiophene & $97-100$ & $332-333$ & 184.26 & $78.2 \%$ & $4.4 \%$ & & & $17.4 \%$ \\
\hline Nitrogen-containing & Acridine & 107 & 346 & 179.22 & $87.1 \%$ & $5.1 \%$ & & $7.8 \%$ & \\
\hline \multirow{4}{*}{$\begin{array}{l}\text { Nitrogen-containing } \\
\text { (Amino group) }\end{array}$} & N-Phenyl-1-Naphthylamine & $60-62$ & 226 & 219.28 & $87.6 \%$ & $6.0 \%$ & & $6.4 \%$ & \\
\hline & Carbazole & 246.3 & 355 & 167.21 & $86.2 \%$ & $5.4 \%$ & & $8.4 \%$ & \\
\hline & Phenothiazine & 184 & 371 & 199.27 & $72.3 \%$ & $4.6 \%$ & & $7.0 \%$ & $16.1 \%$ \\
\hline & $\begin{array}{l}\mathrm{N}, \mathrm{N}^{\prime} \text {-Di-2-naphthyl- } \\
\text { p-phenylenediamine }\end{array}$ & 215 & - & 360.46 & $86.6 \%$ & $5.6 \%$ & & $7.8 \%$ & \\
\hline
\end{tabular}

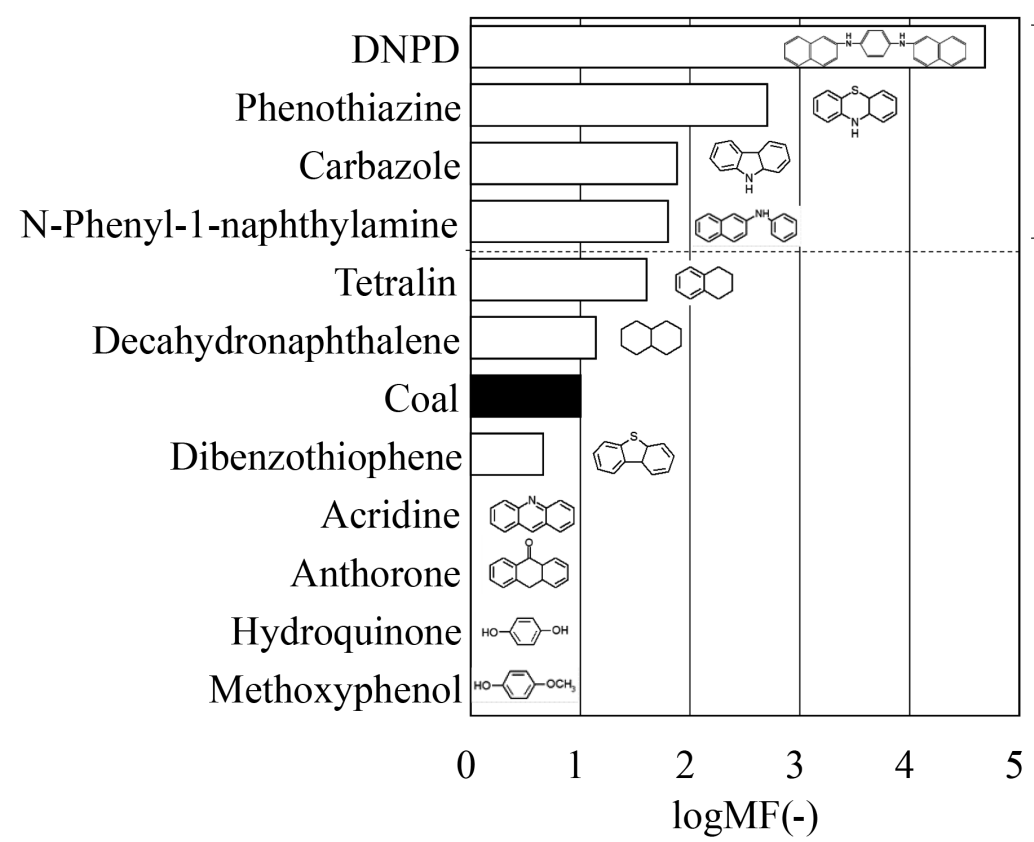

Amino group

Fig. 1. $\log \mathrm{MF}$ of coal and coal with $10 \mathrm{wt} \%$ additives. 
MFが向上するものと，低下するもの2 種類に分かれた。

まず, 酸素, 窒素および硫黄を含有する添加材は Coal A のMFを低下させた。特にアントロン，ヒドロキノン，メト キシフェノール, アクリジン, ジベンゾチオフェン添加時 にCoal Aは熱可塑性をほとんど示さなくなった。Tsubouchi $ら^{11)}$ は, 酸素官能基を含む添加材が MFに負の影響を及ほ すことを報告しており, 酸素官能基は水素受容体として石 炭中の移行性水素を消費することを示唆している。本結果 は, 添加材中の酸素に加え, 窒素および硫黄も水素受容体 として挙動し，MFを低下させたことを示唆している。

次に, 芳香族アミンと炭化水素添加時はCoal Aの MF は 向上した。特に, フェノチアジン, N-フェニル-1-ナフチ ルアミン, カルバゾール, DNPDのような芳香族アミンは Coal AのMFを大きく向上させた。既往の研究から, 石炭 の軟化溶融挙動のメカニズムは未だ完全には明らかになっ ていないものの, 石炭中の移行性水素が軟化溶融温度域に おいて, 石炭の熱分解フラグメントの安定化に寄与するこ とにより, 液相を発達させる重要な役割を持つことが知ら れている ${ }^{12)}$ 。また, 石炭の溶媒に対する溶解度は溶媒の種 類によって異なり，極性溶媒である芳香族アミンはアミノ 基内の窒素原子が非結合電子を有し，電子供与体として挙 動することから，石炭を溶解する優れた溶媒であることが 知られている ${ }^{13)}$ 。本試験においては，芳香族アミンのアミ ノ基は水素供与体として挙動し, アクリジンの窒素は水素 受容体として挙動し石炭の流動性を低下させたものと推察 される。

Fig.2 に MF と添加材である芳香族アミンの分子量との 関係を示す。多環芳香族に関する既報の結果 ${ }^{8,9)}$ と同様に, MF と添加材の分子量との間には相関があると考えられ る。Fig.3に示すように，添加材中に含まれるアミノ基の割 合 $(\mathrm{mol} / \mathrm{g})$ と MFの間に相関は確認できなかったことから, 添加材中に含まれるアミノ基の割合よりも，軟化溶融温度 域における添加剂の残存割合の方が MFに強く影響してい る可能性が示唆された。

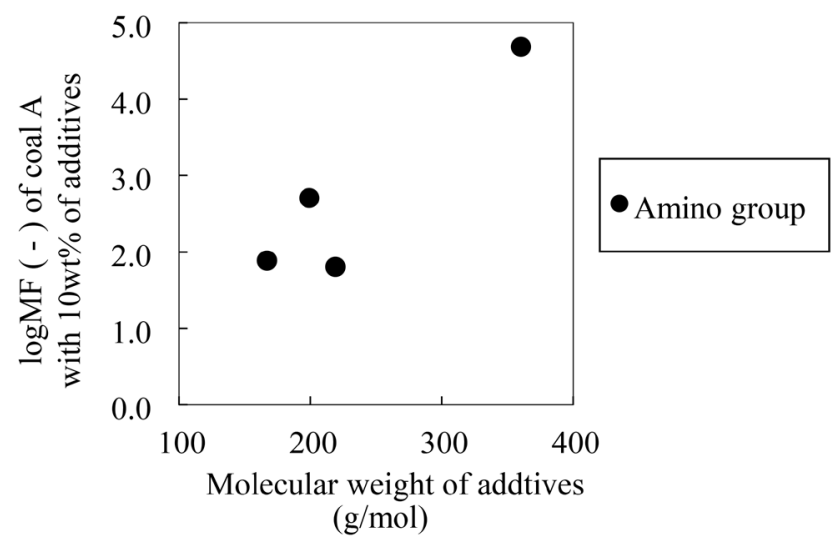

Fig. 2. Relationship between molecular weight of additives and MF.
今回の添加材の中で最も MF改善効果の高いDNPD と石 炭の相互作用を確認するため, TG 分析を行った。Fig.4に Coal A，DNPD，およびCoal A と DNPDの混合物（DNPD 10 $w t \%)$ の TG曲線を示す。DNPD と石炭 Aの混合物の重量減 少は算術平均で導出した計算值より低温で起こり, $873 \mathrm{~K}$ での重量減少割合は計算值より少なかった。石炭の熱分解 温度が低下しコークス歩留が改善されたことから, 軟化溶 融温度範囲で残存している DNPD と石炭の間に何らかの相

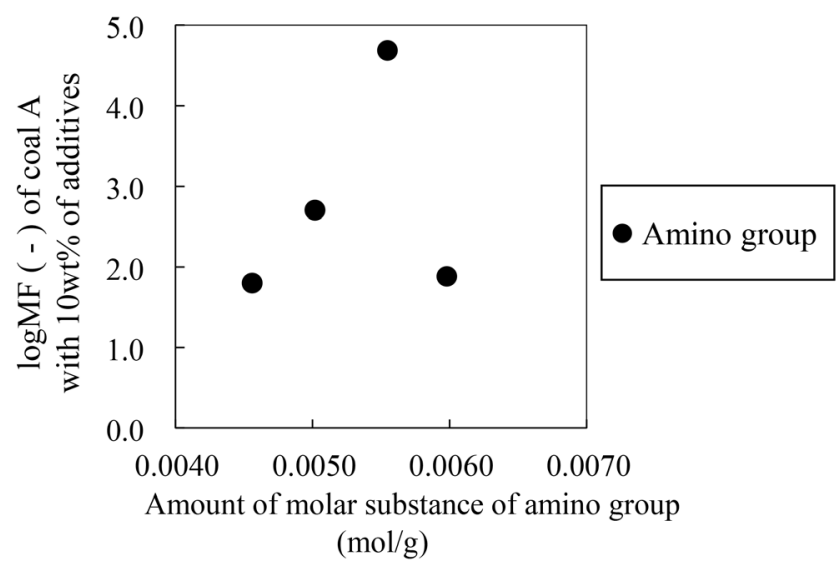

Fig. 3. Relationship between amount of molar substance of amino group and MF.

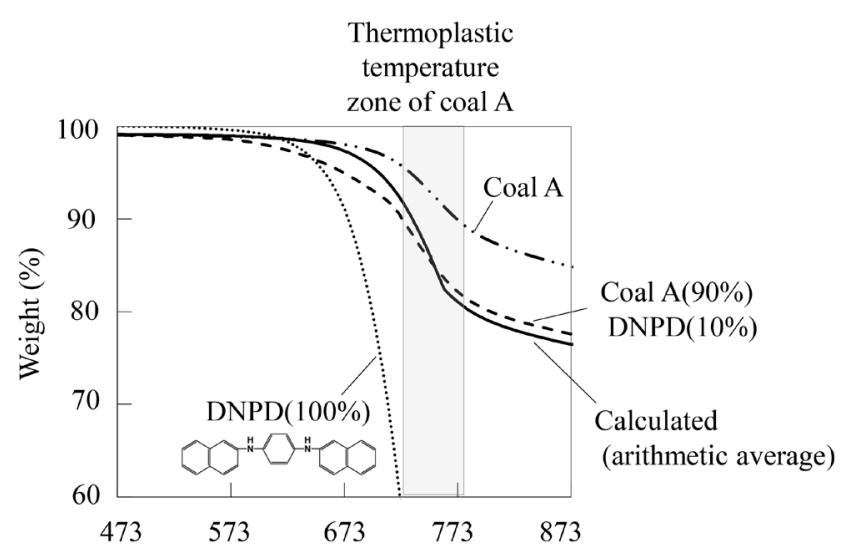

Fig. 4. Thrmogravimetric analysis of coal A with/without DNPD.

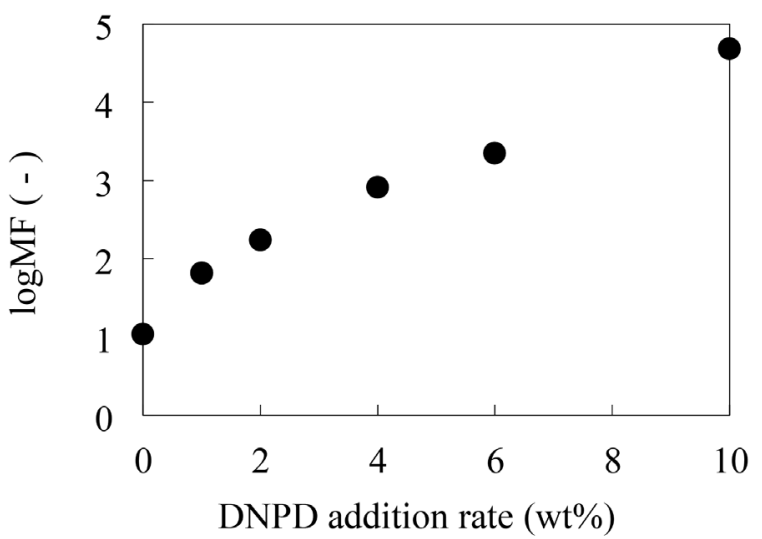

Fig. 5. Relationship between DNPD addition rate and logMF. 
互作用が起きていることが推察される。

Fig.5にDNPDの添加率とCoal AのMFの関係を示す。 DNPDの添加率が高いほど Coal Aの MF は向上している ことがわかる。わずか $1 \mathrm{wt} \%$ 添加時においても, Coal Aの MF は約 0.8 向上している。Fig.6にDNPDの添加率と軟化 開始温度, 最高流動度温度, 固化温度の関係を示す。添加 率が増加すると軟化開始温度は低下する一方で, 最高流 動度温度, 固化温度は軟化開始温度ほど大きく変化しな かった。この結果は, DNPDが軟化溶融温度域中の低い温 度域で石炭の軟化溶融性に影響することを示唆している。 Takanohashi ${ }^{14)}$ は石炭の連続自己溶解モデルを提案して いる。このモデルにおいては，まず石炭中の軽質成分が分 解して溶媒となり，次により重質な成分がそれらの溶媒に 溶解し，これらの現象が連続的に起こるものとしている。 軟化開始温度の低下とMFの向上は, DNPDが石炭の軟化 開始温度より低い温度で溶媒として存在し, 石炭の溶融を 促進させていることを示唆している。また, 沸点が高い添 加材ほど, 軟化溶融温度域においても揮発せずに石炭の溶 融を促進する溶媒として残存することができるので, MF の向上効果が高くなっていることが推察できる。結論とし て, 水素供与体として挙動する芳香族アミンが石炭のMF を向上させ, MF 向上効果と添加材の沸点の間には相関が あることが示唆された。

\section{3. 石炭流動性とコークス強度に及ぼす 芳香族アシンの添加効果}

\section{$3 \cdot 1$ 実験}

Fig.5に示すように, DNPDを $1 \mathrm{wt} \%$ 添加時においても単 味の石炭の MFは 0.8 向上した。今回, 配合炭の MF とコー クス強度に及ぼすDNPDの影響を確認するために，ギー セラープラストメータ試験と配合炭の乾留試験を行った。 Table 3 に配合炭で使用した石炭の性状を示す。Ro, MFは, JIS M8816，M8801に準拠して測定した。まず，Table 4に示 すようにRo, MFの異なるBlend 1, Blend 3, Blend 5を作製

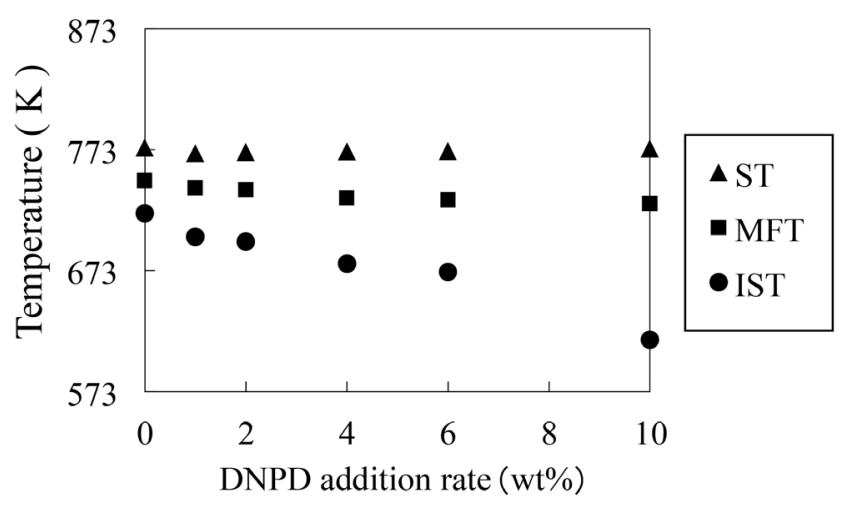

Fig. 6. Relationship between IST, MFT, ST of coal and DNPD addition rate.
し，それらに $1.0 \mathrm{wt} \%$ もしく $1.5 \mathrm{wt} \%$ の DNPDを添加した ものをBlend 2, Blend 4, Blend 6 とした。Blend 1〜Blend 6 は ギーセラープラストメータ法に準拠して流動度の測定を 行った。その後, Blend 1, Blend 2 を Table 5 に示す条件で電 気炉にて乾留し，乾留後のコークス強度をJIS K2151に基 づいて測定した。また，コークス組織については偏光顕微 鏡 (Leica Microsystem model DM2500P) を用いて, 倍率500 倍の条件下，ポイントカウント（200点）を行い，コークス 組織の存在割合を測定した。組織形状と大きさ等から，等

Table 3. Coal properties.

\begin{tabular}{ccccc}
\hline Coal brand & Ro $(\%)$ & TI $(\%)$ & VM (wt\% d.b.) & logMF $(-)$ \\
\hline Coal B & 1.36 & 46.20 & 19.60 & 0.60 \\
Coal C & 1.17 & 4.80 & 26.80 & 1.83 \\
Coal D & 1.00 & 38.90 & 26.20 & 0.95 \\
Coal E & 0.93 & 31.60 & 29.50 & 2.68 \\
Coal F & 0.81 & 13.70 & 36.70 & 3.50 \\
Coal G & 0.70 & 12.10 & 40.70 & 3.67 \\
Coal H & 1.61 & 44.30 & 18.00 & 0.00 \\
Coal I & 1.46 & 17.90 & 20.10 & 0.78 \\
Coal J & 1.35 & 46.90 & 19.50 & 0.60 \\
Coal K & 1.25 & 42.40 & 21.20 & 1.91 \\
Coal L & 1.05 & 31.10 & 25.80 & 2.69 \\
Coal M & 0.94 & 29.50 & 28.20 & 2.47 \\
Coal N & 0.67 & 17.20 & 42.70 & 3.80 \\
\hline
\end{tabular}

Table 4. Coal blending conditions.

\begin{tabular}{|c|c|c|c|}
\hline Coal brand & Blend1 Blend2 & Blend3 $\quad$ Blend 4 & Blend5 Blend6 \\
\hline Coal B (wt $\%)$ & 10.0 & & \\
\hline Coal C (wt\%) & 4.5 & & \\
\hline Coal D (wt\%) & 35.6 & & \\
\hline Coal E (wt\%) & 30.0 & & \\
\hline Coal F (wt\%) & 10.0 & & \\
\hline Coal G (wt\%) & 9.9 & & \\
\hline Coal H (wt\%) & & 10.0 & \\
\hline Coal I (wt\%) & & 4.5 & 5.0 \\
\hline Coal J (wt\%) & & 7.2 & 8.0 \\
\hline Coal K (wt\%) & & 18.0 & 20.0 \\
\hline Coal L (wt\%) & & 18.0 & 20.0 \\
\hline Coal M (wt\%) & & 31.5 & 35.0 \\
\hline Coal N (wt\%) & & 10.8 & 12.0 \\
\hline Ro (\%) & 0.97 & 1.11 & 1.05 \\
\hline $\log \mathrm{MF}(-)$ & 2.00 & 2.10 & 2.33 \\
\hline DNPD (\%) & 0.0 & 1.5 & 1.5 \\
\hline
\end{tabular}

Table 5. Carbonization test conditions.

\begin{tabular}{cc}
\hline & Blend 1,2 \\
\hline Coal size $(\mathrm{wt} \%)$ & $-3 \mathrm{~mm}: 85 \%,+6 \mathrm{~mm}: 5 \%$ \\
Moisutre content $(\mathrm{wt} \%)$ & 8.0 \\
Bulk density $\left(\mathrm{kg}-\mathrm{dry} / \mathrm{m}^{3}\right)$ & 870 \\
Retort size $(\mathrm{mm})$ & W365 $\times$ H431 $\times$ L565 \\
Wall temperature $(\mathrm{K})$ & 1373 \\
Coking time $(\mathrm{min})$ & 1200 \\
\hline
\end{tabular}


方性組織, 微粒モザイク組織, 粗粒モザイク組織, 繊維状 組織, 葉片状組織の 5 種類に判別した。

\section{$3 \cdot 2$ 結果と考察}

Fig.7 に示すように, 配合炭品位の影響を確認するため, Ro, MFの異なる配合炭にDNPDを 1.0 または $1.5 \mathrm{wt} \%$ 添加 した三種類の配合炭のMF測定を行った。三種類の配合炭 全てのケースに打いて, MFは $1 \mathrm{wt} \%$ 当り約 0.4 改善され た。Fig.8 に添加率と配合炭の軟化開始温度, 最高流動度 温度，固化温度の関係を示す。配合炭の軟化開始温度は 1 wt $\%$ あたり約 $10 \mathrm{~K}$ 程度低下しており，Fig.6に示す単味炭 の結果と同程度だった。DNPDの添加量 $1 \mathrm{wt} \%$ あたりの軟 化開始温度の低下は単味炭と配合炭でほとんど同じだっ たのに対し，MF向上効果は配合炭の方が低かった。Matsui $ら^{15)}$ は配合炭の実測MF は計算MFより低く, 石炭化度の ばらつきが大きいほど計算 MF と実測MFの差が大きくな ることを報告している。これは，石炭化度が高い石炭は低 温域で固相として存在し，見かけ粘度を上げるからであ る。また, 極性溶媒中の石炭の溶解度は石炭化度および元 素比率に依存することが報告されており ${ }^{16)}$, DNPDが単味 炭に及ぼす MF 向上効果も炭種によって異なっている可能 性がある。配合炭は石炭化度と元素比率にばらつきのある 複数の石炭の混合品であり, それぞれの石炭で軟化溶融

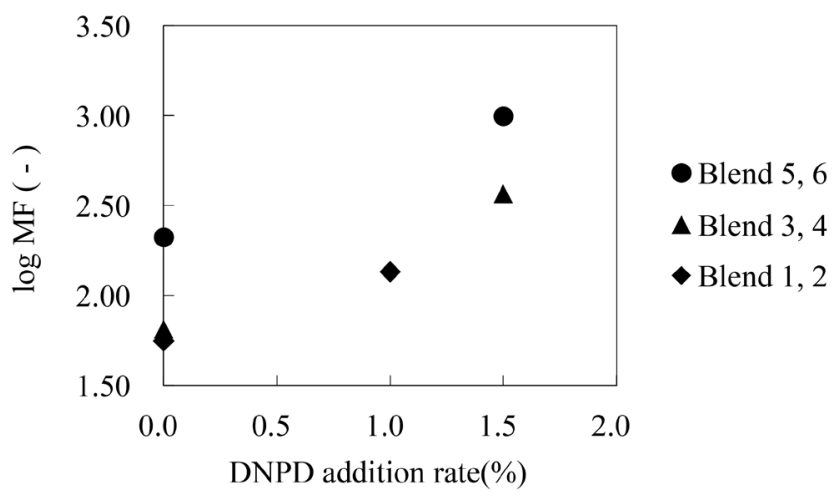

Fig. 7. Effect of DNPD addition on MF of blending coal.
開始温度が異なり，かつDNPDのMF向上効果が石炭種に よっては低い可能性もあることから, 単味炭より配合炭で MF 向上効果が低くなったものと推察される。

Fig.9に配合炭のコークス強度と実測MFの関係を示す。 配合炭のMFが向上するとともに，コークス強度は6ポイ ント改善した。Miyazu ら ${ }^{2)}$ は, 高強度コークスを製造す るためには配合炭の MF は2.3 以上が必要なことを報告し ている。本結果は，流動性支配領域に打ける配合炭MFが DNPDの添加により向上したことでコークス強度が改善し たものと推察される。

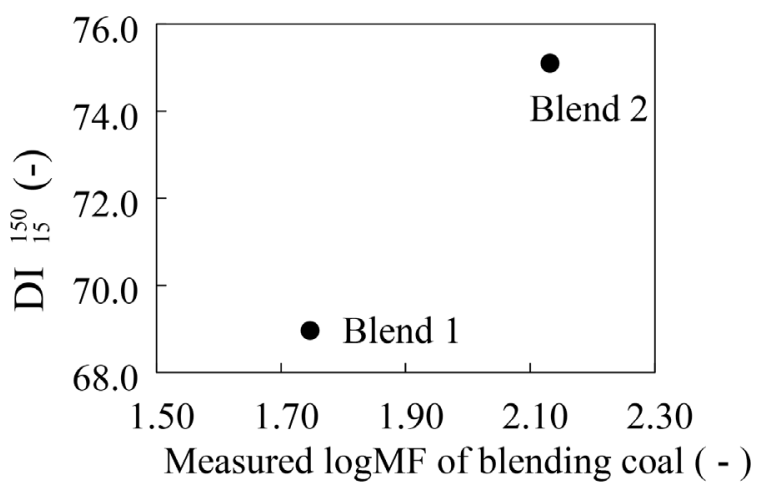

Fig. 9. Effect of DNPD addition on coke strength.

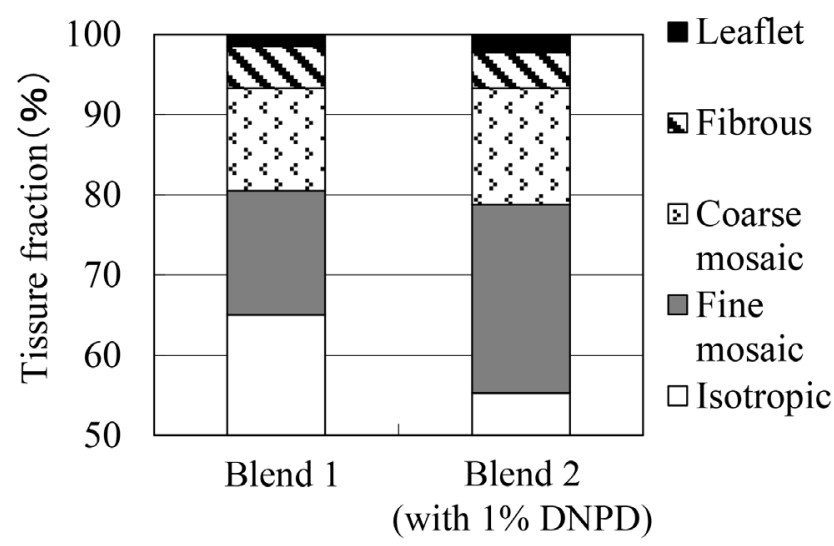

Fig. 10. Effect of DNPD addition on optical anisotropy of coke.

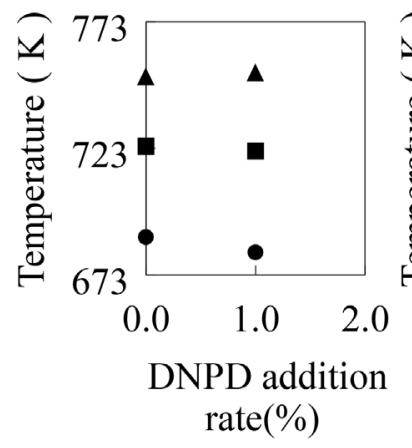

(a) Blend 1,2

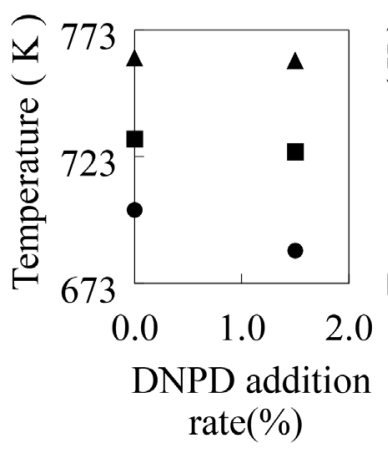

(b) Blend 3,4

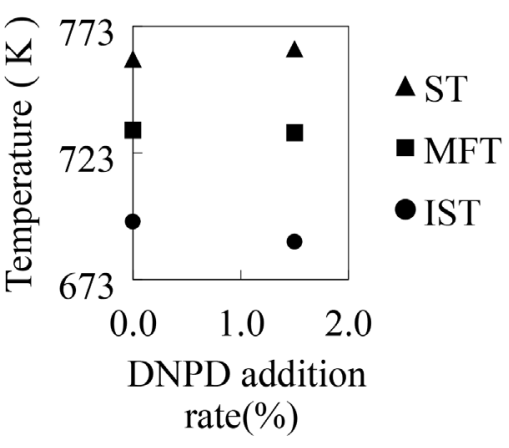

(c) Blend 5,6

Fig. 8. Relationship between IST, MFT, ST of coal blends and DNPD addition rate. 
Fig.10にBlend 1 と, DNPDを $1 \mathrm{wt} \%$ 添加したBlend 2 にお けるコークス組織の割合を示す。DNPDを $1 \mathrm{wt} \%$ 添加する だけで等方性集合組織の割合が減少し，異方性集合組織の 割合が相対的に増加した。本結果は，DNPDが石炭の軟化 溶融温度域で溶媒として存在し, 液相化を促進してコーク ス組織とその強度を改善させたものと考えられる。

結論として, DNPDの $1 \mathrm{wt} \%$ のの添加でも，配合炭の $\mathrm{MF}$ とコークス強度，およびコークス組織の異方性を大き く改善させることが明らかになった。

\section{4. 結論}

石炭の流動性向上に有効な化学物質を探索するために, 酸素, 窒素, 硫黄を含有する 11 種の多環芳香族炭化水素の 石炭流動性への添加効果を調査した結果，以下の知見を得 た。

(1) 窒素, 硫黄および酸素含有化合物添加時に石炭のMF は低下した一方で, 芳香族アミン添加時は石炭の MF が改善した。

(2) MF改善効果と芳香族アミン添加材の分子量には相関 があり, N, N'-ジ-2-ナフチル-1, 4-フェニレンジア ミン (DNPD) が本研究に打いて最も向上効果が高かっ た。

（3）配合炭にDNPDをわずか $1 \mathrm{wt} \%$ 添加した場合において も，配合炭のMF および乾留後のコークス強度，コーク ス組織の異方性が改善することを確認した。

\section{文献}

1 ) T.Ariyama, M.Sato, T.Sato, S.Watakabe and R.Murai: Tetsu-toHagané, 92(2006), 114 (in Japanese).

2 ) T.Miyazu, Y.Okuyama, Y.Suzuki, T.Fukuyama and T.Mori: NKK Tech. Rep., 67(1975), 125 (in Japanese).

3 ) H.Kimura: Tetsu-to-Hagané, 64(1978), 2257 (in Japanese).

4 ) H.Izuhara, A.Kitahara and S.Nishida: J. Fuel Soc. Jpn., 63(1984), 775 (in Japanese).

5 ) Y.Kiritani, M.Tsuyuguchi and N.Nire: J. Fuel Soc. Jpn., 51(1972), 639 (in Japanese).

6 ) T.Nishi, K.Shiraishi, Y.Miura, H.Uematsu and Y.Yone: Tetsu-toHagané, 68(1982), 2141 (in Japanese).

7 ) T.Shishido, K.Sakai, N.Okuyama, M.Hamaguchi and N.Komatsu: Kobe Steel Eng. Rep., 60(2010), 62 (in Japanese).

8 ) Y.Fujioka, K.Saito and K.Kato: Proc. Conf. Coal Sci., 43(2006), 119.

9 ) K.Koyano, K.Ueoka, T.Takanohashi, K.Fukada and K.Ota: Tetsuto-Hagané, 96(2010), 224 (in Japanese).

10) N.Tsubouchi, Y.Mochizuki, Y.Ono, K.Uebo, T.Takanohashi and N.Sakimoto: ISIJ Int., 54(2014), 2439.

11) N.Tsubouchi, Y.Mochizuki, R.Nagayama, K.Kamiya, M.Nishio, Y.Ono and K.Uebo: Energy Fuel., 30(2016), 2095.

12) M.Nomura, S.Murata, K.Kidena, T.Chikata and S.Nomura: Thermoplasticity Mechanism of Coal Particles, ISIJ, Tokyo, (2001), 61.

13) S.Otani and Y.Sanada: Tansokakogaku-no-kiso (Basics of Carbon Chemical Engineering), Ohmsha, Tokyo, (1980), 179 (in Japanese).

14) T.Takanohashi, T.Yoshida, M.Ino, K.Kato, K.Fukada and H.Kumagai: Structure and Thermoplasticity of Coal, Nova Science Publishers, New York, (2005), 31.

15) T.Matsui, K.Igawa and K.Sorimachi: Tetsu-to-Hagané, 82(1996), 480 (in Japanese).

16) Y.Sanada: J. Fuel Soc. Jpn., 57(1978), 3 (in Japanese). 